ОРГАНІЗАЦІЙНО-ПСИХОЛОГІЧНІ ЧИННИКИ АКАДЕМІЧНОЇ ПРОКРАСТИНАЦІЇ У СТУДЕНТІВ

\title{
ORGANIZATIONAL AND PSYCHOLOGICAL DETERMINANTS OF PROCRASTINATION IN STUDENTS
}

За останні роки збільшилась чисельність студентської молоді, яка схильна відкладати виконання навчальних завдань. Якщо така поведінка має тимчасовий характер і від цього суттєво не погіршується академічна успішність, то вона не помітна, однак має тенденцію перерости у звичну. Негативного забарвлення навчальне відтермінування набуває на постійній основі. Науковці позначають че явище як академічну прокрастинацію. Вивчення та аналіз чинників академічної прокрастинації допоможуть розробити есрективні технології навчання та попередження переростання відтермінувань у студентів у звичну практику.

Автори статті тлумачать академічну прокрастинацію як якісне новоутворення в структурі особистості, на яке можуть тією чи іншою мірою впливати різноманітні чинники, і досліджують психологічні та організаційні причини ї̈ виникнення. Серед них здатність до self-менеджменту, мотивація учбової діяльності, психологічний клімат та згуртованість студентської групи, організація навчального процесу (фрорма навчання, стиль викладання, навантаження курсу, система заохочень), особливості навчальних завдань та діяльності (складність і тривалість у часі навчальних завдань).

Методи наукового дослідження: теоретичні - аналіз та синтез інорормації, порівняння, класифрікація та систематизація, метод теоретичного узагальнення; емпіричні опитування, анкетування; методи статистичного аналізу даних.

Результати емпіричного дослідження: загалом академічна прокрастинація (АП) наявна у всіх досліджуваних; суттєвої різниці у прояві АП між студентами бюджетної та контрактної форм навчання не виявлено. Причиною відтермінування завдань у більшості випадків (62\%) є надто великий термін для виконання. Студенти, які практикують самоменеджмент, мають нижчі показники АП. У студентів із внутрішньою мотивацією до навчання рівень АП нижчий, аніж у студентів із зовнішньою. У студентів з високим рівнем иілеспрямованості показники АП вищі, аніж у студентів з середнім рівнем. Встановлено, що між академічною прокрастинацією та наполегливістю і планомірністю особистості існує обернений кореляційний зв'язок; існує обернений кореляційний зв'язок між соціально-психологічним кліматом колективу, контролем викладача за навчальною діяльністю, значимістю та складністю завдань та рівнем академічної прокрастинації; відсутній зв'язок між згуртованістю колективу та рівнем академічноі прокрастинації; виявлено наявність сильних обернених кореляційних зв'язків між плануванням, цілепокладанням та академічною прокрастинацією.

Ключові слова: прокрастинація, студентська молодь, академічна прокрастинація, згуртованість, self-менеджмент, мотивація, соціально-психологічний клімат.

In recent years, there has been an increase in the number of students who tend to put off aca demic tasks. If such behavior is of temporary nature and does not significantly affect academic performance, it is not evident; however, it tends to become a habitual pattern. Academic delays acquire a negative coloring on a regular basis. Scholars refer to this phenomenon as academic procrastination. The study and analysis of causes of academic procrastination will help to develop instructional tools to effectively educate students and reduce the level of their procrastination. We interpret this phenomenon as a new qualitative formation in the personality structure, which can be more or less influenced by various factors; we also investigate psychological and organizational causes of academic procrastination. They include self-management ability, motivation for academic activities, psychological climate and solidarity in the student group, educational process arrangement, as well as specific features of academic tasks and activities.

Research methods: theoretical - information analysis and synthesis, comparison, classification and systematization, method of theoretical summarizing; empirical - survey, questioning; methods of statistical data analysis.

Empirical findings: academic procrastination $(A P)$ in general is observed in all the respondents; there is no significant discrepancy in the manifestation of AP between students of state-financed and contractual forms of education. The reason for postponing tasks in most cases (62\%) is too long a deadline for their fulfillment. Stu dents practicing self-management show lower levels of $A P$. Intrinsically motivated students demonstrate a lower level of AP than extrinsically motivated students do. Students with a high level of determination show higher levels of $A P$ as compared to students with an average level of determination.

Empirical research reveals the following: there is an inverse correlation between academic procrastination and persistence and consistency of personality; there is an inverse correlation between the social and psychological climate in the team and the level of academic procrastination; there is no relationship between group solidarity and the level of academic procrastination; there is high inverse correlation between planning, goal-setting and academic procrastination. Based on the elaborated questionnaire, we are able to establish that there is no relationship between the form of study and the level of manifestation of academic procrastination. We find a strong inverse relationship between teach er's control of academic activities and the level of manifestation of academic procrastination among students.

Key words: procrastination, student youth, academic procrastination, solidarity, self-management, motivation. 
В умовах стрімкого розвитку новітніх технологій до сучасної людини збільшується ряд вимог, які стосуються переважно розвитку соціальних навичок, успішності в усіх сферах діяльності. Навіть більше, великий наплив інформації ставить завдання критично осмислювати все, що відбувається навколо. Не кожен здатен витримувати таке навантаження, і внаслідок цього виникає новий феномен сучасності - прокрастинація. Це певна настанова, що включає когнітивний, емоційнооцінковий, конативний компоненти. На думку В. Ковиліна, прокрастинація тісно пов'язана з мотиваційною сферою особистості і найчастіше проявляється у професійній діяльності, піклуванні про здоров'я, у навчанні [1].

Зарубіжні вчені почали досліджувати явище прокрастинації лише на початку $70-x$ років XX століття. Перші науково обґрунтовані дослідження проводили Н. Мілграмм, Дж. Баторі, Д. Моурер, які розробили першу класифікацію видів прокрастинації. Зокрема, Н. Мілграм у своїй педагогічній діяльності тісно співпрацював із здобувачами, застосовував інтерактивні методи навчання та оригінальну систему оцінювання. Тому питання академічної прокрастанації студентської молоді викликало у вченого цілком зрозумілий інтерес. Даний вид прокрастинації був виведений Н. Мілграмом у 1992 р., при цьому він визначав ще чотири види. Та через деякий час його класифікація змінилась і включала в себе лише два види: прокрастинація у виконанні завдань та у прийнятті рішень. Академічну прокрастинацію відносимо до першого виду [2]. Пізніше К. Лей визначав прокрастинацію як особистісну негативну характеристику [3]. Дж.Р. Феррарі, Дж. Джонсон, У. Маккоун та інші дотримувалися погляду на прокрастинацію як на позитивний феномен [4].

Американська дослідниця Л.А. Ребін у 2010 р. вивчала вплив форми навчання на виникнення у студентів прокрастинації. Було встановлено, що для багатьох студентів тенденція до відкладання зростає під час онлайн-навчання. На традиційних заняттях вимога відвідувати лекції і семінари змушує студентів вчитися, акцентувати увагу на навчальних матеріалах на регулярній основі. Принаймні частина їнього часу навчання розподіляється однаково упродовж семестру. Студентів онлайн-навчання не змушують брати участь у регулярних аудиторних заняттях, тому існує підвищена тенденція до зволікання. Студенти більше вивчають за менший проміжок часу, і часто це призводить до нижчих результатів навчання. Л.А. Ребін зазначила, що студенти онлайн-навчання мають вищі показники академічної прокрастинації, аніж студенти денної форми [5].
Е.Дж. Онвугбузі вивчав такі чинники прокрастанації, як тривожність особистості, страх невдачі і особливості навчального завдання. Спираючись на праці Л.Дж. Соломон і Е.Д. Ротблюма, він пояснює, що головна причина зволікання - це страх невдачі і неприйнятність завдання. Страх невдачі включає компоненти, пов'язані з оцінкою тривоги та надто перфекціоністськими стандартами для виконання завдань, а також низький рівень упевненості у собі. Вчений зазначає, що важливість завдань позитивно корелює 3 виникненням академічної прокрастинації. Тобто чим важливіше завдання, тим воно здається складнішим i, як наслідок, виникає страх невдачі та бажання відтермінувати виконання завдань [6].

Вітчизняні вчені зацікавилися питанням академічної прокрастинації наприкінці XX ст. Зокрема, С.М. Соболєва, С.В. Мохова здійснили аналіз явища академічної прокрастинації у світлі психолого-педагогічної проблеми і серед чинників прокрастинації розглядають не лише особистісні якості, а й організацію навчального процесу та науково-педагогічну діяльність викладачів, яка прямо не залежить від студента [7]. М.С. Дворник вивчала типи відтермінувальних практик, визначила такі причини виникнення академічної прокрастинації: необхідність підтримки чи контролю оточуючих; неготовність до виконання завдань; особистісна нерішучість; страх відповідальності; незацікавленість у виконанні завдань; орієнтація на соціальну винагороду [8]. М.А. Кузнєцов розглядав прокрастинацію як чинник емоційного ставлення студентів до навчальної діяльності. Учений встановив, що під час вираженої прокрастинації знижується позитивне та гіпертрофується негативне ставлення до навчання. Також у даному дослідженні було встановлено, що студенти з середнім рівнем академічної прокрастинації мають найвищі показники тривожності [9].

Також проводилось багато інших досліджень академічної прокрастинації у її зв'язку 3 перфекціонізмом і мотивацією студента (Т.В. Зарипова, Н.А. Данилова, А.С. Лавренко, М.В. Ларських, Н.Г. Матюхіна).

Не менш важливим $€$ аналіз впливу групи, зокрема організаційних процесів, таких як згуртованість і соціально-психологічний клімат, вплив більшості або меншості на виникнення у студентів академічної прокрастинації. Так, ідентифікація з групою впливає на самосприйняття та усвідомлення свого призначення; співпраця з групою дозволяє продуктивніше вирішувати завдання, ніж самостійна діяльність; під впливом групи людина стає більш активною й ефективною.

Огляд наукових доробок зарубіжних і вітчизняних вчених засвідчив про достатньо висо- 
кий рівень розробки заявленої проблематики. Однак недостатньо вивченим залишається питання впливу організаційних та організаційно-психологічних чинників. Тому метою статті $\epsilon$ виявлення та обґрунтування впливу організаційно-психологічних чинників на академічну прокрастинацію у студентів.

На основі теоретичного аналізу вітчизняних та зарубіжних вчених ми визначили такі чинники впливу на академічну прокрастинацію:

1. Організаційні: організація навчального процесу і особливості навчальних завдань. Показниками цього чинника $є$ : форма навчання (денна, контрактна); стиль викладання; навантаження курсу (кількість годин); система заохочень; складність і тривалість у часі навчальних завдань.

2. Організаційно-психологічні: саморегуляція (вміння спрямувати свої навчальні процеси шляхом відповідних цілей та застосувати впливи, які мотивують до діяльності); важливість завдання для студента; групові процеси (згуртованість та соціально-психологічний клімат групи), самоменеджмент студента (уміння цілепокладання і планування).

3. Психологічні: мотивація до успіху; самооцінка (самоповага, впевненість у собі); локус контролю (екстернальний чи інтернальний); перфекціонізм.

Методико-технологічний рівень становлять конкретні методи та методики наукового дослідження: теоретичні - аналіз та синтез інформації, порівняння, класифікації та систематизації, метод теоретичного узагальнення; емпіричні - анкетування, опитування, зокрема шкала прокрастинації для студентів (С. Лей) [10]; «Опитувальник самоорганізації діяльності» (Е.Ю. Мандрикова) [11]; методики «Діагностика соціально-психологічного клімату» (О.С. Михалюк) та «Визначення ціннісно-орієнтаційної єдності групи» (В.С. Івашкін, В.В. Онуфрієва) [12]; авторська анкета для дослідження організаційно-психологічнихчинників. Аналіз отриманих даних здійснювався за допомогою методів математичної статистики, а саме: коефіцієнт кореляції Пірсона, точковий бісеріальний коефіцієнт. Значущість статистичного показника встановлювалась на основі врахування критичних значень відповідно до об'ємів емпіричної вибірки за рівня статистичної значущості $p \leq 0,05$. Для обробки даних застосовувалася програма Exel.

Дослідження проводилося на базі філософського факультету ДВНЗ «Прикарпатський національний університет імені Василя Стефаника». Всі респонденти навчалися за спеціальністю «Психологія». Вибірка включала 62 студента віком від 17 до 22 років.

На початку дослідження важливо було виявити академічну прокрастинацію в опитуваних та визначити її рівень прояву. Для цього ми скористалися методикою С. Лей. Високий рівень академічної прокрастинації було виявлено у 74 відсотків досліджуваної вибірки, середній рівень - у 26 відсотків. При цьому студентів, у яких не простежується дане явище, не виявлено. Отримані результати дали можливість перейти до наступного етапу дослідження, а саме до вивчення причин академічного відтермінування. 3 допомогою розробленої анкети "Організаційні чинники академічної прокрастинації», в якій містилися питання відкритого та закритого типу щодо причин відтермінування, ми дізналися, що поширеною причиною відтермінування академічних завдань $€$ терміни виконання $-64 \%$. Тобто прокрастинація виникає, якщо терміни здачі академічного завдання $€$ надто великими, або ж часу не достатньо. На другому місці - складність завдань. Цей показник становить 18 відсотків. Важливо, що відтермінування проявляється, якщо студент вважає, що завдання надто складне. Відсутність мотивації до навчання як причину прокрастинації вказали 14 відсотків респондентів. I показник «інше» становить 4\%. До категорії «інше» були віднесені небажання виконувати завдання конкретних дисциплін, нестача часу.

Наступною досліджувалася здатність студентів до самоменеджменту. Сюди входять навички планування та цілепокладання. Було встановлено, що 14 відсотків студентів планують власну діяльність, але не ставлять віддалені цілі. Йшлося не лише про навчання, а й про інші види діяльності. Студентів, що займаються лише цілепокладанням, 18 відсотків. Студентів, які і планують і ставлять цілі, 26 відсотків від загальної кількості. Загалом самоменеджмент практикують 58 відсотків усіх респондентів.

Наступним чинником $є$ мотивація виконання навчальних завдань. Показники зовнішньої мотивації: оцінки за виконане завдання, стипендія, диплом; внутрішньої мотивації отримання знань (саморозвиток), інтерес до навчання. Отримання високої оцінки як мотивація до виконання навчальних завдань становить 36 відсотків від усіх опитаних. Далі йде бажання отримати стипендію (14\%), диплом (12\%). Важливо, що отримання диплому як мотивація переважає у студентів контрактної форми навчання. Внутрішня мотивація переважає у студентів бюджетної форми навчання (23\%). Мотив отримання нових знань становить 18 відсотків від усіх досліджуваних; мотив навчального інтересу - 20 відсотків. При цьому рівень академічної прокрастинації нижчий у студентів з внутрішньою мотивацією. Це пояснюється навчальним інтересом до дисциплін, а також баченням кінцевої мети навчання.

Ще один чинником виникнення академічної прокрастинації $€$ значимість виконання 
академічних завдань для студентів. Важливість виконання академічних завдань відображає послідовність, з якою студент виконує завдання. 34 відсотки опитаних зазначили, що спершу виконують ті завдання, які мають короткий термін виконання. Для 18 відсотків важливим $€$ контроль викладача. Стільки ж студентів під час виконання орієнтуються на навчальний інтерес до дисципліни. На отримання високої оцінки або ж уникнення незадовільного балу, орієнтовані 10 відсотків студентів. 12 відсотків опитаних зазначили, що для них не важливий жоден з перелічених чинників. Це означає, що студент виконуватиме спочатку ті завдання, у яких короткий термін здачі, або ж якщо викладач здійснює постійний контроль за виконанням.

Далі досліджувалося вміння планувати та організовувати власну діяльність з допомогою методики Е.Ю. Мандрикової «Самоорганізація діяльності». За шкалою «Планомірність» встановлено такі результати: високі показники (30\%), середні (34\%) і низькі (36\%). Тобто 30 відсотків респондентів залучені до щоденного тактичного планування. Решта студентів роблять це з перервами або ж узагалі не планують діяльність. Результати опитування за шкалою «Цілеспрямованість»: високий рівень цілеспрямованості і здатність концентруватися на меті демонструють 80 відсотків опитуваних; середній рівень - 20 відсотків. За шкалою «Наполегливість» визначено, що у 38 відсотків наявний високий рівень; у 36 відсотків - середній; у 26 відсотків - низький рівень наполегливості. Це означає, що у більшої половини досліджуваних спостерігається слабовиражена схильність до докладання вольових зусиль для завершення початої справи та впорядкованої активності. За шкалою «Фіксація» виявлено високий рівень у 76 відсотків опитаних студентів, середній рівень - у 22 відсотків і низький рівень фіксації - у 2 відсотків. Це означає, що у більшості студентів наявна ригідність у відношенні планування, залежність від чіткого розкладу. За шкалою «Самоорганізація» виявлено таке: високий і середній рівень самоорганізації діяльності у 26 відсотків опитуваних, низький рівень у 48 відсотків. Тобто 52 відсотки досліджуваних використовують зовнішні ресурси в організації діяльності. Результати опитування за шкалою «Орієнтація на теперішнє»: високий рівень за даною шкалою у 60 відсотків респондентів, середній рівень у 30 відсотків, низький рівень орієнтації у 10 відсотків. Тобто більшість орієнтовані на сьогодення і не ставлять віддалених цілей, що підтверджують дані, отримані з допомогою анкети.

Загалом академічна прокрастинація (АП) наявна у всіх досліджуваних. Суттєвої різниці у прояві АП між студентами бюджетної та контрактної форм навчання не виявлено. Студенти, які практикують самоменеджмент, мають нижчі показники АП. У студентів з внутрішньою мотивацією до навчання рівень АП нижчий. У студентів з високим рівнем цілеспрямованості показники АП вищі, аніж у студентів з середнім рівнем.

Ще одним чинником прокристанації є соціально-психологічний клімат групи. Для його визначення ми використовували методику О.С. Михалюк та А.Ю. Шалито. Так, 56 відсотків студентів вважають, що у їхній групі сприятливий соціально-психологічний клімат; для 38 відсотків у колективі малосприятливий клімат; для 6 відсотків - несприятливий. Вивчення згуртованості студентських груп здійснювалося за методикою В.С. Івашкін, В.В. Онуфрієва. За результатами дослідження було встановлено: найвищий рівень згуртованості наявний у студентів 5 групи (47\%); 32 відсотки - рівень 4 групи; у групі 3 рівень згуртованості - 22 відсотки; у групі 2 та 1 - по 31 і 33 відсотки відповідно.

Наступним етапом дослідження було встановлення кореляційних зв'язків між організаційно-психологічними чинниками та академічною прокрастинацією за допомогою кореляційного аналізу Пірсона. Так, між академічною прокрастинацією (АП) та «Планомірністю» наявний обернений кореляційний зв'язок $r_{x}=-0,306305$ (значимість 0,01); між АП та «Наполегливістю» існує обернений зв'язок $r_{x}=-0,372412$ (значимість 0,01). Отже, чим нижчими будуть рівень цілеспрямованості та рівень планомірності у студентів, тим вищим буде прояв академічної прокрастинації.

Кореляційний аналіз чинника згуртованості групи з академічною прокрастинацією дав наступні результати: $r_{x}=-0,132361$. Це означає, що рівень згуртованості корелює з академічною прокрастинацією на рівні статистичної значимості 0,05. Тобто згуртованість колективу має незначний вплив на виникнення академічної прокрастинації у досліджуваній вибірці студентів. Окрім цього чинника, досліджувався рівень соціально-психологічного клімату колективу (СПК). Тут кореляція встановлювалася за допомогою кореляційного аналізу Пірсона: $r_{x}=-0,356386$. Тобто між академічною прокрастинацією та рівнем соціально-психологічного клімату наявний єдиний обернений кореляційний зв'язок. Це означає, що чим нижчий рівень СПК, тим вищий рівень академічної прокрастинації.

Окрім цього, кореляційний аналіз здійснювався за допомогою точкового бісеріального аналізу. Цей тип аналізу використовували для дослідження зв'язку між самоменеджментом та академічною прокрастинацією. В поняття «самоменеджмент» ми включали навички планування та цілепокладання. Між умінням 
планувати та академічною прокрастинацією існує непрямий кореляційний зв'язок $\mathrm{R}_{\mathrm{pb}}=$ -0,410307 зі значимістю 0,01. Це свідчить про те, що чим краще розвинена навичка планування діяльності, тим нижчим буде рівень академічної прокрастинації. Показники зв'язку цілепокладання і АП такі: $\mathrm{R}_{\mathrm{pb}=}-0,480370$ - сильний обернений зв'язок зі значимістю 0,01. Тобто низький рівень цілепокладання може впливати на рівень АП. Можна стверджувати, що відсутність вміння ставити цілі сприятиме появі академічної прокрастинації.

Наступним досліджувалися форма навчання, контроль викладача за діяльністю та особливості навчальних завдань у зв'язку з академічною прокрастинацією. До уваги бралася денна бюджетна та денна контрактна форми навчання. Згідно з результатами кореляційно аналізу бачимо, що форма навчання не впливає на виникнення академічної прокрастинації, оскільки зв'язок цих показників на рівні $R_{\mathrm{pb}}=0,013251$. Зв'язку фактично немає.

Далі вивчався зв'язок між академічною прокрастинацією та контролем викладача за навчальною діяльністю. Дані були зібрані за допомогою анкети. Між академічною прокрастинацією та контролем викладача за навчальною діяльністю існує сильний обернений кореляційний зв'язок $\mathrm{R}_{\mathrm{pb}}=-0,410352$ зі статистичною значимістю 0,01. Це означає, що чим більший контроль за навчальною діяльністю, тим менший прояв академічного відтермінування.

Проведене емпіричне дослідження дозволило нам встановити, що між академічною прокрастинацією та наполегливістю і планомірністю особистості існує обернений кореляційний зв'язок; існує обернений кореляційний зв'язок між соціально-психологічним кліматом колективу та рівнем академічної прокрастинації; відсутній зв'язок між згуртованістю колективу та рівнем академічної прокрастинації; виявлено наявність сильних обернених кореляційних зв'язків між плануванням, цілепокладанням та академічною прокрастинацією. Доведено, що такі особливості навчальних завдань, як складність та терміни здачі, не впливають на виникнення академічного відтермінування у студентів. За допомогою розробленої анкети вдалося встановити відсутність зв'язку між формою навчання та рівнем прояву академічної прокрастинації. Виявлено сильний обернений зв'язок між контролем викладача за навчальною діяльністю та рівнем прояву академічної прокрастинації у студентів. Перспективи подальших напрацювань вбачаємо у вивченні організаційно-психологічних чинників академічної прокрастанації у студентів, які навчаються на дистанційній формі навчання.

\section{ЛIТЕРАТУРА:}

1. Ковилин В.С. Теоретические основы изучения феномена прокрастинации Личность в меняющемся мире: здоровье, адаптация, развитие. 2013. № 2 (2). C. 22-41.

2. Milgram N.A. Procrastination: A malady of modern time. Boletin de Psicologia. 1992. Vol. 35:83. 102 p.

3. Lay C. At last, my research article on procrastination. Journal of Research in Personality. 1986. № 20. P. 474-495.

4. Ferrari J.R., Johnson J.L., McCown W.G. Procrastination and task avoidance. New York : Plenum Press, 1995. 273 p.

5. Rabin L., Fogel J., Nutter-Upham K. Academic procrastination in college students: The role of selfreported executive function. Journal of clinical and experimental neuropsychology. 2011, 33(3). P. 344-357.

6. Onwuegbuzie Anthony J. Academic procrastination and statistics Anxiety. Assessment \& Evaluation in Higher Education. Vol. 29, No. 1, February 2004.

7. Соболєва С.М. Академічна прокрастинація як психолого-педагогічна проблема. Гуманітарний вісник ДВНЗ «Переяслав-Хмельницький державний педагогічний університет імені Григорія Сковороди». Педагогіка. Психологія. Філософрія. 2014. Вип. 34. С. 190-197.

8. Дворник М.С. Соціально-психологічні практики відтермінування в конструюванні особистістю власного майбутнього : дис .канд. психол. Наук : 19.00.05. Київ, 2014 р. 215 с.

9. Кузнєцов М.А. Прокрастинація як чинник емоційного ставлення студентів до навчальної діяльності. Вісник Дніпропетровського університету. Серія «Психологія». 2016 р. Вип. 22. С. 61-70.

10. Лей С. Шкала прокрастинації для студентів. Опитувальник. URL: http://xn----7sbbaeiowbgqig8abjb c7acdh6a9czc6mla.xn--p1ai/downloads.php?downloa.

11. Мандрикова Е.Ю. Разработка опросника самоорганизации деятельности. Психологчческая диагностика. 2010. № 2. 25 с.

12. Фетискин Н.П., Козлов В.В., Мануйлов Г.М. Социально-психологическая диагностика развития личности и малых групп. Москва, 2002. 490 с. 